\title{
PRODUCTION OF 11 $\alpha$-HYDROXYPROGESTERONE USING ASPERGILLUS TERREUS IMMOBILIZED ON POLYTETRAFLUOROETHYLENE
}

\author{
E.M.Ahmed \\ Natural and Microbial Products Chemistry Dept., National Research Center, Dokki, Cairo, Egypt \\ Submitted: July 07, 2006; Returned to authors for corrections: September 04, 2006 Approved: February 12, 2007.
}

\begin{abstract}
In attempt to immobilize the mycelial fungi on a new hydrophobic matrix, Aspergillus terreus mycelia were immobilized into polytetrafluoroethylen (PTFE) and used for selected conversion of progesterone to $11 \alpha$ hydroxyprogesterone. The immobilized cells exhibited higher yields than the free cells. Different parameters that can affect the cell activity were measured. The optimum pH was 6 and the optimum temperature was $30^{\circ} \mathrm{C}$. Higher transformation activities were achieved with matrix contained $40 \%$ PTFE. No considerable loss in yield was observed with storage of the cells at $4^{\circ} \mathrm{C}$ for 30 days. Utilization of the immobilized cells in repeated batch processes indicated that the cells retained about $84 \%$ of their activity after reuse for eight successive cycles.
\end{abstract}

Key words: $11 \alpha$-hydroxprogesterone, polytetrafluoroethylene, Aspergillus terreus

\section{INTRODUCTION}

Immobilization of microorganisms for biotransformation of steroids received increasing attention over the last several years $(3,7,11,15,20,22)$. However, immobilization of fungal mycelia is difficult and often results in subsequent loss of many metabolic activities due to damage of the cells. Consequently, retention of the cells activities after immobilization is critical for the success of the immobilization process (12). Generally, there are few detailed and comprehensive studies on immobilization. Selection of the support material and the method of immobilization is made by measuring the properties and limitations characteristics of support materials and immobilization techniques. The main shortcomings of isotropic xerogel carriers are low durability and the mass transfer problem $(14,17,28)$. One of the feasible approaches for reduction of mass transfer resistance to diffusion of the substrate materials is to immobilize the cells into a thin film or on the surface of a membrane $(2,10)$. Another possibility is to immobilize the cells in a fibrous matrix, attained by natural attachment or crosslinking to the fibers (10).

Immobilization of cells within a hydrogel creates significant mass transfer resistance e.g. hindrance of substrate diffusion into/out the immobilized cells (26).
The use of hydrophobic immobilization matrices especially for biotransformation of hydrophobic substrates may allow for more favorable diffusion conditions (30). The operational and diffusion conditions should be carefully optimized since high stirring speeds or liquid phase flow rates can cause the rupture the immobilization matrix (9).

Polytetrafluoroethylene (PTFE) is an inert hydrophobic material that can be processed to form a porous fibril structure having mechanical strength and thermal stability $(6,13,25,27)$. PTFE is a crystalline polymer with high melting temperature. It forms a stable melt even at $380^{\circ} \mathrm{C}$, with a typical melt viscosity 10GPas. Under atmospheric conditions, PTFE has two transition temperatures at $19^{\circ} \mathrm{C}$ and $30^{\circ} \mathrm{C}$. Below $19^{\circ} \mathrm{C}$, PTFE particles are very hard and shearing will cause its crystals to slide paste each other retaining their identity. Above $19^{\circ} \mathrm{C}$, PTFE molecules are packed more loosely and shearing will cause the unwinding of crystallites creating fibrils $(5,24)$. These fibrils interconnect the particles, creating a network and giving dimensional stability to the formed paste. Above $30^{\circ} \mathrm{C}$, a higher degree of fibrillation can be achieved (24), and PTFE paste extrusion can be performed near ambient temperature producing a mechanically strong product (24). In this process, the paste formed from PTFE resin is treated to remove air and

*Corresponding Author. Mailing address: Natural and Microbial Products Chemistry Dept., National Research Center, Dokki, Cairo, Egypt. E-mail: eahmed1998@yahoo.com 
reduce undesired voids. The conditions of paste formation play a crucial role since the liquid distribution within the paste depends on these conditions (5). Operational conditions such as selecting level and duration of applied pressure ensure that even liquid distribution inside the paste is attained. This helps in obtaining PTFE with acceptable mechanical properties $(1,19)$.

This investigation aimed at the utilization of PTFE as a new compatible carrier for filamentous fungi. The scope of the work was to investigate the ability of the cells to withstand the harsh immobilization process and to evaluate the potency of the immobilized cells to withstand different stresses of a transformation process. Transformation of poorly soluble progesterone into $11 \alpha$-hydroxyprogesterone $(11 \alpha-\mathrm{HP})$ was selected as an ideal transformation process. Importance of $11 \alpha-$ $\mathrm{HP}$ as anti-inflammatory agent and in synthesis of cortisone is well known $(23,29,31)$. Specific characteristics of the immobilized cells such as the ability to ensure long term repeated batch processing, stability to stirring conditions, substrate concentrations and $\mathrm{pH}$ and temperature variation were targeted. During the experiments the biochemical characteristics of the immobilized cells were determined on the basis of conversion of progesterone. To best of our knowledge this is the first time for PTFE, to be used as a carrier for filamentous fungus.

\section{MATERIALS AND METHODS}

Chemicals: chemicals used in this work were purchased from Sigma Chemicals Co., St. Louis, MO and Fluka. The organic solvents were AR grade.

Microorganisms: the Aspergillus terreus strain was obtained from Natural and Microbial Products Chemistry Department., National Research Center, Cairo, Egypt. The fungus was maintained on slants containing medium composed of infused white potato 300 , Glucose 20 and agar $20(\mathrm{~g} / \mathrm{l})$ at $4^{\circ} \mathrm{C}$. The slants were subcultured monthly.

Medium and culture conditions: the inoculum was transferred from slants to Erlenmeyer flasks ( $250 \mathrm{ml}$ ) containing $50 \mathrm{ml}$ sterile medium composed of (g/l): Sucrose 20, $\mathrm{NaNO}_{3} 2, \mathrm{KH}_{2} \mathrm{PO}_{4} 1.0$, $\mathrm{KCl} 0.5, \mathrm{Mg}_{2} \mathrm{SO}_{4} .7 \mathrm{H}_{2} \mathrm{O} 0.5, \mathrm{FeSO}_{4} .7 \mathrm{H}_{2} \mathrm{O}$ 0.005. The $\mathrm{pH}$ of the medium was adjusted to 5.6 and the spore concentration was $3 \times 10^{6} / \mathrm{ml}$. The flasks were incubated on rotatory shaker at $27^{\circ} \mathrm{C}$ and $150 \mathrm{rpm}$ for $48 \mathrm{~h}$.

Immobilization technique: the mycelial cells in the medium were harvested by filtration and washed with saline solution. A slurry of PTFE particles $(0.05-0.5 \mu \mathrm{m})$ in emulsion (approx. 60\% by weight) was added dropwise to the cells suspension to a final concentration of $30 \%(\mathrm{w} / \mathrm{w})$. The formed mixture was then centrifuged at $4000 \mathrm{rpm}$ for $15 \mathrm{~min}$. The supernatant was removed and the mixture was washed with phosphate buffer and centrifuged again. The mixture was placed in Petri dish and pressed carefully with a rubber mill in different directions to form a thick membrane of approximately $3 \mathrm{~mm}$ thickness. The resulting membrane was cut into pieces.

Biotransformation technique: the membrane pieces containing the immobilized cells were suspended in $250 \mathrm{ml}$ Erlenmeyer flasks containing $50 \mathrm{ml}$ of the same medium prepared for growing the cells. The $\mathrm{pH}$ of the medium was adjusted to 5.6. Ten $\mathrm{mg}$ of progesterone dissolved in appropriate amount of absolute alcohol were added to each flask. The flasks were incubated on rotary shaker at $27^{\circ} \mathrm{C}$ and $150 \mathrm{rpm}$. After the specified transformation period, the content of each flask was extracted three times with equal volume of chloroform. The extracts were combined and washed with sodium bicarbonate $(2 \%)$, dried over anhydrous sodium sulfate and evaporated to form the test material $(8,18)$.

Qualitative analysis: the test materials were dissolved in chloroform:methanol $(1: 1 \mathrm{v} / \mathrm{v})$. The transformation products in the test material were detected by TLC using silica gel G60 (18). Cyclohexane:chloroform:isopropanol (10:5:2) was used as developing solvent system. The transformation products were identified after comparison with a standard product.

Quantitative analysis: the transformation products (11 $\alpha-\mathrm{HP}$ and progesterone) in $1 \mathrm{ml}$ of sample (test materials) were assayed spectrophotometrically $(8,18)$, and the results were confirmed using HPLC (HP, Agilent series 1100, USA). HPLC analysis was performed under the following conditions: Hi Plex Pb column (Schimadzu, PL, USA), detection at $254 \mathrm{~nm}$, flow rate $1 \mathrm{ml} / \mathrm{min}$ and methanol:water (70:30 v/v) as solvent system. Minor side products were neglected. All experiments were carried out in duplicate and the averages were taken.

\section{RESULTS AND DISCUSSION}

\section{Effect of time}

The optimum time for production of $11 \alpha$-hydroxyprogesterone using the immobilized cells is shown in Fig. 1. The highest yield of $11 \alpha-\mathrm{HP}$ was achieved after $12 \mathrm{~h}$ of incubation both by immobilized and free cells. The yield by achieved immobilized cells and free cells were $42 \%$ and 34 respectively. $11 \alpha$-HP output decreased gradually with increase of time, reaching the minimum level (11\% for immobilized cells and 6.8\% for free cells) after $72 \mathrm{~h}$. These results indicate that immobilization of the fungal cells improved the transformation activity. In addition, retention of the transformation activity after immobilization gives an advantage to the immobilized cells.

\section{Effect of pH}

When the $\mathrm{pH}$ of the medium varied between 4.5 and 8 , the optimum $\mathrm{pH}$ for transformation was found to be 6 . At this $\mathrm{pH}$, the yield of $11 \alpha$-HP obtained using the immobilized cells was about $44 \%$ (Fig. 2). This $\mathrm{pH}$ was also the optimum for the free cells where $35.50 \%$ yield was detected. The results proved that the immobilized cells were less affected by alkalinity and acidity 


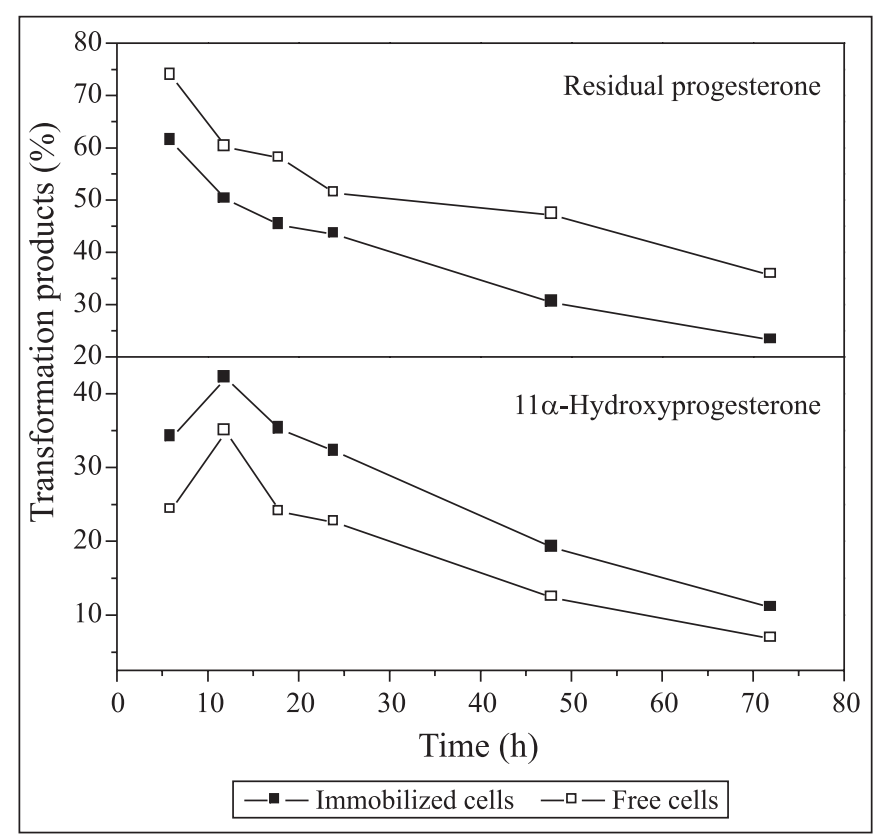

Figure 1. Effect of time on the production of $11 \alpha$ hydroxyprogesterone by cells of $A$. terreus immobilized on PTFE. $\mathrm{pH} 5.6,27^{\circ} \mathrm{C}, 150 \mathrm{rpm}, 30 \%$ PTFE and $10 \mathrm{mg}$ progesterone $/ 50 \mathrm{ml}$ broth.

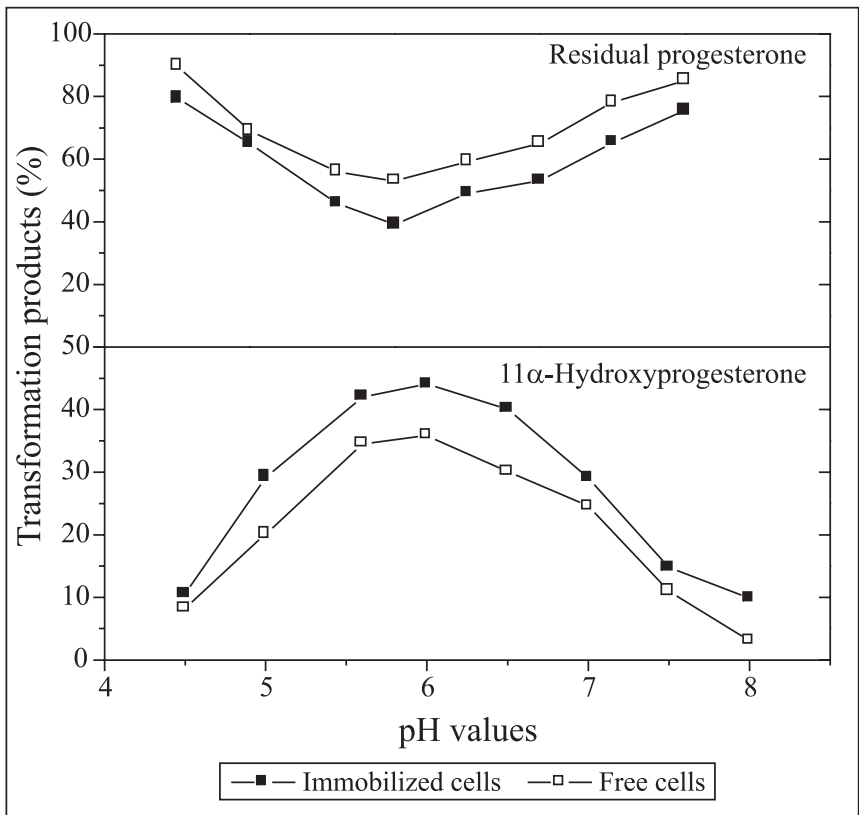

Figure 2. Effect of $\mathrm{pH}$ on the production of $11 \alpha$ hydroxyprogesterone by cells of $A$. terreus immobilized on PTFE. Incubation time $12 \mathrm{~h}, 27^{\circ} \mathrm{C}, 150 \mathrm{rpm}, 30 \%$ PTFE and $10 \mathrm{mg}$ progesterone $/ 50 \mathrm{ml}$ broth. than the free cells. This feature is particularly important in fermentation processes, where there is an expected shift in $\mathrm{pH}$ during the process.

\section{Effect of temperature}

When the temperature was increased gradually from 25 to $45^{\circ} \mathrm{C}$, the highest yields of transformation were attained at $30^{\circ} \mathrm{C}$, for both free and immobilized cells. However, the immobilized cells were more stable at higher temperatures than free cells (Fig. 3), probably due to the increased resistance of the cells inside the thermally stable PTFE matrix.

\section{Effect of shaking}

External mass transfer limitation can be prevented if a suitable hydrodynamic condition is chosen (4). This experiment reflects to certain extent the stability of the biocatalyst to the mechanical stress caused by shaking. Increase of shaking from 50 to 150 rpm increased the yields of $11 \alpha$-HP from $21.5 \%$ to about $52 \%$ (Fig. 4). Further increase of shaking speed caused no considerable change in the amount of formed $11 \alpha-\mathrm{HP}$, indicating that mass transfer is not a limiting factor (21). On the ther hand, the increase of shaking speed to $250 \mathrm{rpm}$ did not cause cracks or ruptures in the membranes.

\section{Effect of PTFE concentration}

The concentration of utilized PTFE was varied from 15 to $50 \%$ (w/w). Fig. 5 shows that a yield of $67.10 \%$ of $11 \alpha-\mathrm{HP}$ was

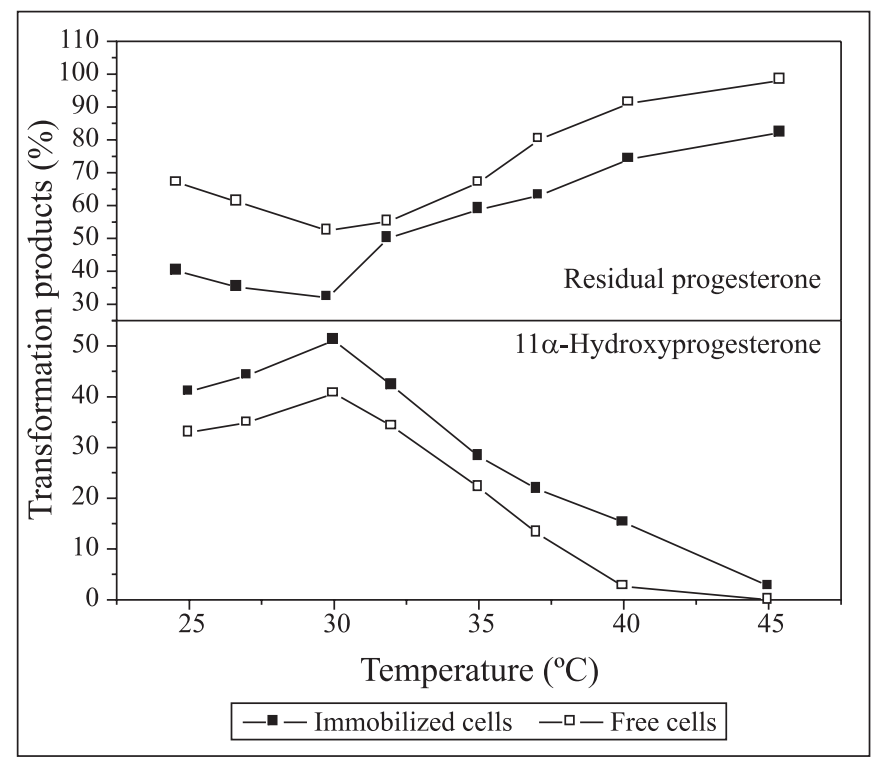

Figure 3. Effect of temperature on the production of $11 \alpha-$ hydroxyprogesterone by cells of $A$. terreus immobilized on PTFE. Incubation time $12 \mathrm{~h}, \mathrm{pH} 6,30 \% \mathrm{PTFE}$ and $10 \mathrm{mg}$ progesterone / $50 \mathrm{ml}$ broth. 


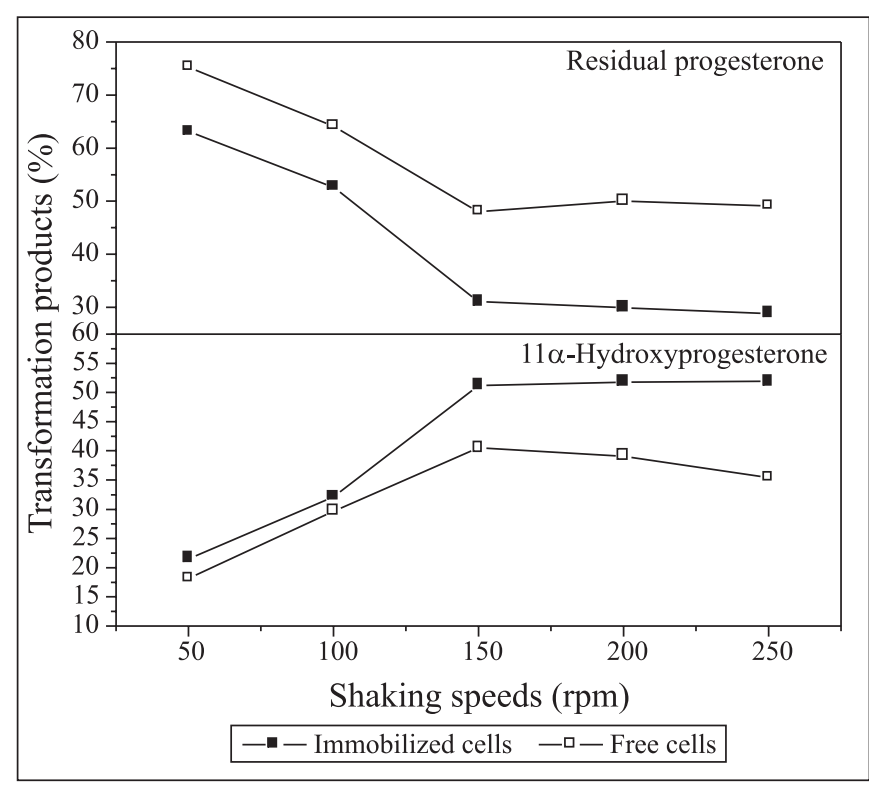

Figure 4. Effect of shaking speed on the production of $11 \alpha-$ hydroxyprogesterone by cells of $A$. terreus immobilized on PTFE. Incubation period $12 \mathrm{~h}, \mathrm{pH} 6,30^{\circ} \mathrm{C}, 30 \%$ PTFE and $10 \mathrm{mg}$ progesterone $/ 50 \mathrm{ml}$ broth.

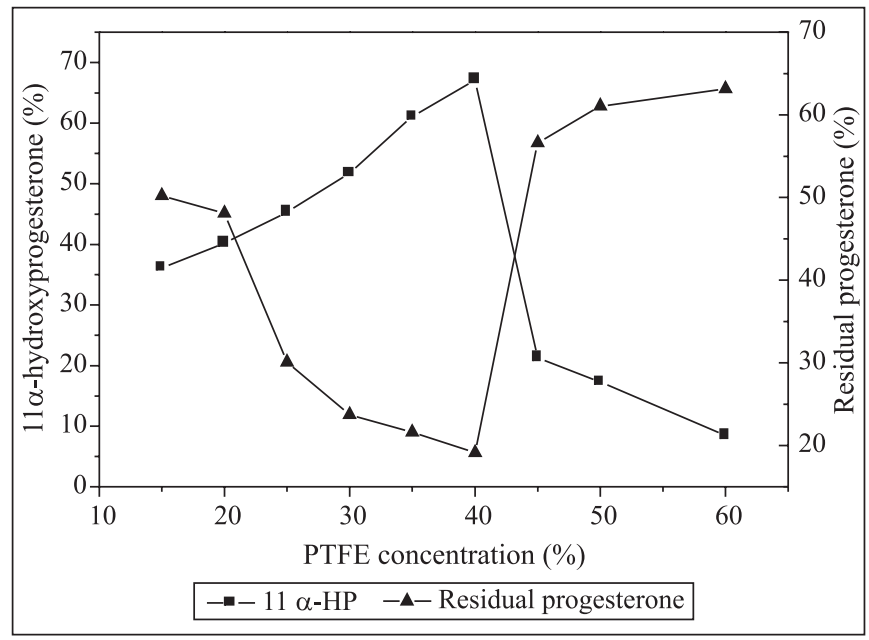

Figure 5. Effect of PTFE concentration on the production of $11 \alpha$ - hydroxyprogesterone by cells of $A$. terreus immobilized on PTFE. Incubation period $12 \mathrm{~h}, 200 \mathrm{rpm}, \mathrm{pH} 6,30^{\circ} \mathrm{C}$ and $10 \mathrm{mg}$ progesterone $/ 50 \mathrm{ml}$ broth.

achieved when a membrane containing 40\% PTFE was used. Membranes containing higher concentrations of PTFE resulted in lower yields. Similarly, low PTFE concentrations resulted in yields reduction. It was noticed that utilization of $15 \%$ PTFE resulted in formation of a weak membrane, with escape of cells.
On the other hand, the yield reduction at high PTFE concentrations may be attributed to hindrance of the nutrients and substrate accessibility to the immobilized cells within the matrix containing excess of PTFE.

\section{Effect of substrate concentration}

Fig. 6 shows that the increment of the substrate concentration retarded the conversion process. The immobilized cells appeared to be less affected than the free cells, probably due to the protection provided by the immobilization against the toxic effect of the substrate. However, the transformation rate was dramatically reduced when the substrate concentration reached $1 \mathrm{mg} / \mathrm{ml}$. Suppression of the reaction at this substrate concentration may have been caused by the blocking of the pores of the matrix, hindering the transport of oxygen and nutrients to the cells. Goetschel and Bar (16) also concluded that the reduction in transformation rate using PVA as carriers was a result of the blocking of the pores by the substrate when high concentration was utilized.

\section{Effect of storage}

The economics of the immobilization process depend on the lifetime of the biocatalyst. The storage stability of the immobilized cells at $-4,4$ and $25^{\circ} \mathrm{C}$ for 15,20 and 30 days is shown in Fig. 7. The most convenient storage was attained at $4^{\circ} \mathrm{C}$ for 30 days where only $1.5 \%$ of the activity was lost. On the other hand, the cells lost $45 \%$ of activity after storage at $25^{\circ} \mathrm{C}$ for 30 days. In general, storage at $-4^{\circ} \mathrm{C}$ and $4^{\circ} \mathrm{C}$ gave better results than at $25^{\circ} \mathrm{C}$.

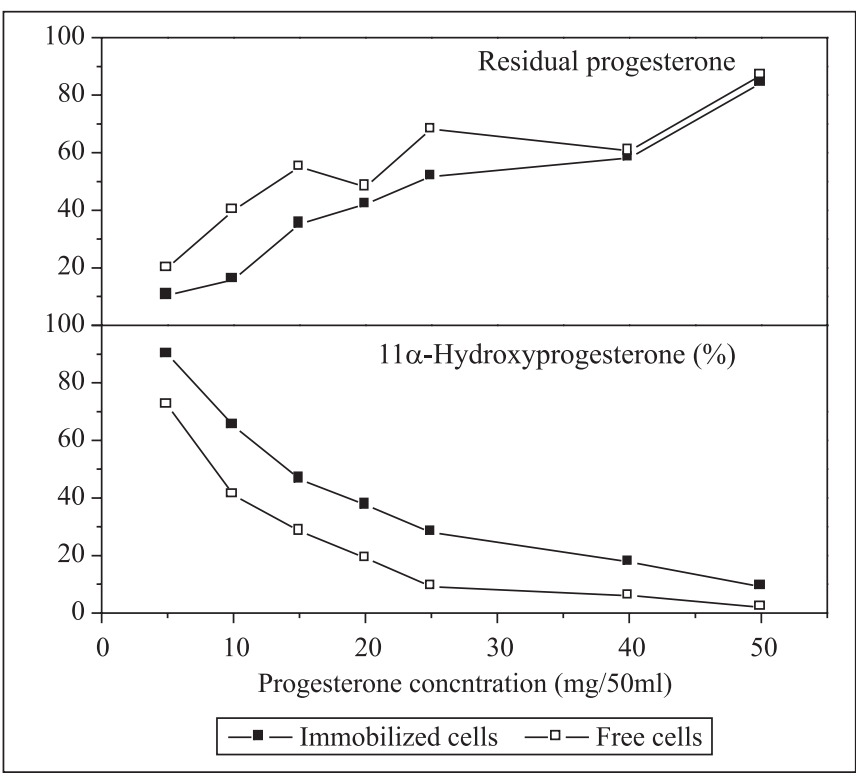

Figure 6. Effect of progesterone concentration on the production of $11 \alpha$-hydroxyprogesterone by $A$. terreus. cells immobilized in PTFE. Incubation period $12 \mathrm{~h}, 200 \mathrm{rpm}, \mathrm{pH} 6,30^{\circ} \mathrm{C}, 40 \%$ PTFE. 


\section{Reusability}

One of the advantages of using immobilized cells is the possibility of their reuse in repeated processes. However, reuse requires high operational stability. The immobilized cells

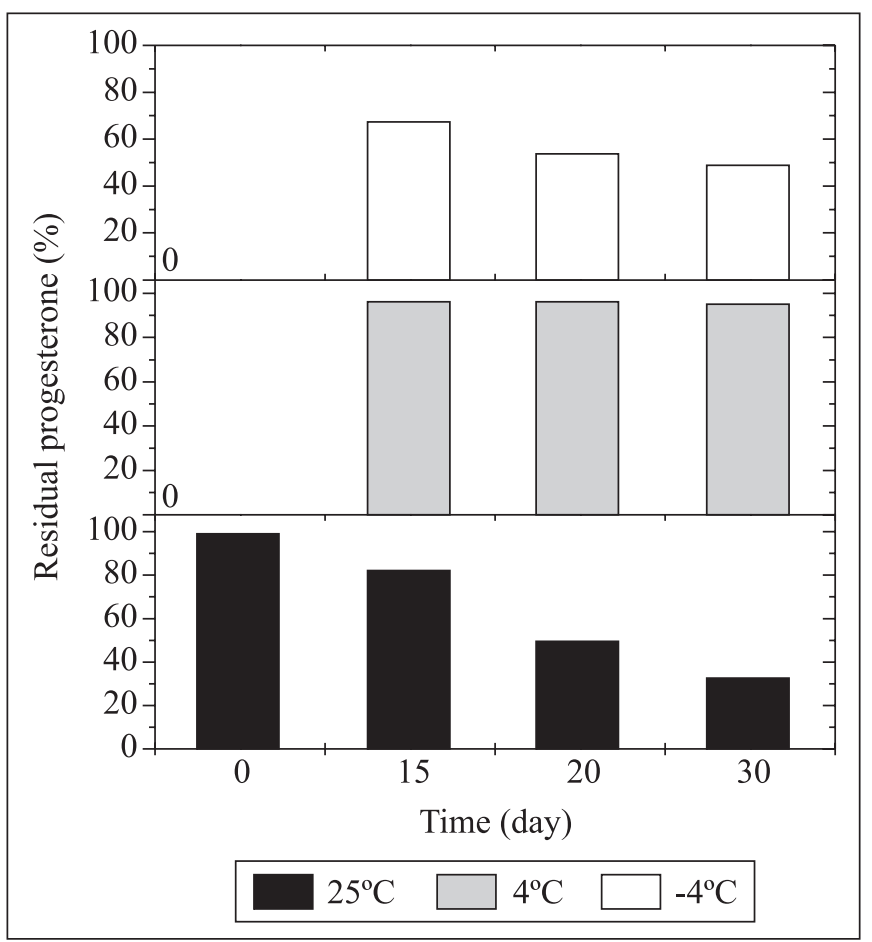

Figure 7. Stability of A. terreus PTFE immobilized cells. Incubation time $12 \mathrm{~h}, 200 \mathrm{rpm}, \mathrm{pH} 6,30^{\circ} \mathrm{C}, 40 \%$ PTFE and $10 \mathrm{mg}$ progesterone $/ 50 \mathrm{ml}$ broth.

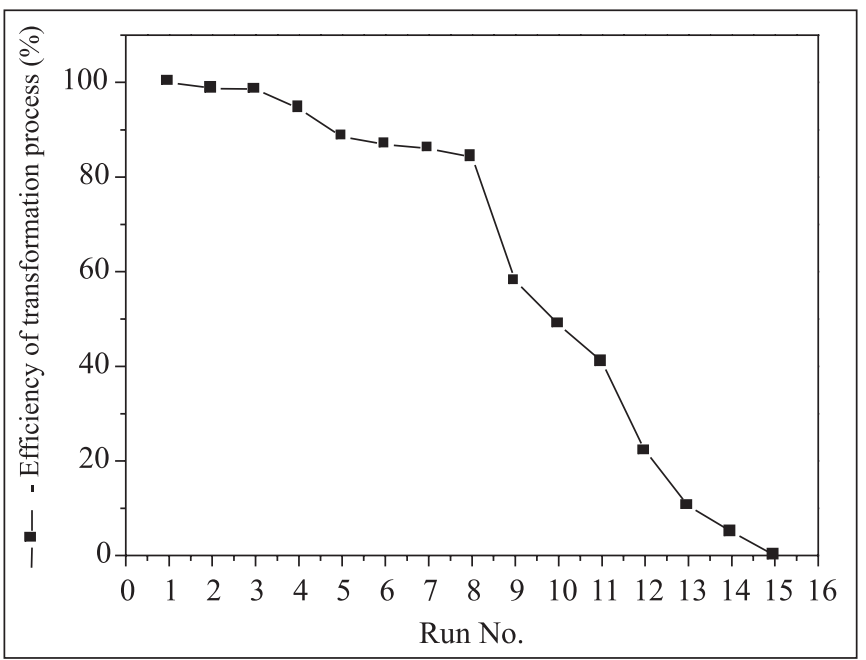

Figure 8. Influence of recycling of the A. terreus PTFE immobilized cells on the efficiency of production of $11 \alpha$ hydroxyprogesterone. obtained under the optimal conditions were repeatedly used for number of successive cycles, and their activity was retained for about 14 cycles (Fig. 8). The conversion efficiency remained at high level (84\%) until cycle eight but decreased afterwards. This high activity after eight cycles is another valuable feature for the immobilization process.

\section{RESUMO}

\section{Produção de 11 $\alpha$-hidroxiprogesterona por Aspergillus terreus imobilizado em politetrafluoretileno}

Com o objetivo de imobilizar o micélio fúngico em uma nova matriz hidrofóbica, o micélio de Aspergillus terreus foi imobilizado em politetrafluoretileno (PTFE) e usado para a conversão de progesterona em $11 \alpha$-hidroxiprogesterona. As células imobilizadas apresentaram rendimento melhor que as células livres. Diferentes parâmetros que afetavam a atividade celular foram avaliados. $\mathrm{O}$ pH ótimo foi 6 e a temperatura ótima foi $30^{\circ} \mathrm{C}$. Verificou-se que a atividade de transformação era mais elevada quando a matriz continha $40 \%$ de PTFT. Não houve perda significativa de atividade após o armazenamento das células a $4^{\circ} \mathrm{C}$ por 30 dias. Utilizando-se as células imobilizadas em partidas repetidas, verificou-se que mantinham cerca de $84 \%$ da atividade após oito ciclos sucessivos.

Palavras-chave: $11 \alpha$-hidroxiprogesterona, politetrafluoretileno, Aspergillus terreus

\section{REFERENCES}

1. Ariawan, B.A.; Ebesajjad, S.G.; Hatzikriakos, S. (2001). Performing behavior of polytetrafluoroethylene paste. Powder Technol., 121, p.249.

2. Ascencio, F.; Johansson, G.; Wadstram, T. (1995). Cell-surface and cell surface hydrophobicity of collagen-binding Aeromonas and Vibrio strains. Arch. Microbiol., 164, 223-230.

3. Atrat, P. (1982). Steroids transformation with immobilized microorganisms. Z. Allg. Microbiol., 22, 723-761.

4. Ballesteros, A.; Boross, L.; Bucholz, K.; Cabral, S.M.J.; Kasche, V. (1993). In Cabral, S.M.J.; Best, D. and Tramper, J. (eds) Appl. Biocatal., Harwood Academic Publishers. p.237.

5. Bendow, J.J.; Bridgwater, J. (1993). Paste flow and extrusion. Oxford University press, NY.

6. Bhushan, B. (2002). Introduction to Tribology. John Wiley and Sons, USA. pp.266.

7. Bihari, V.; Goswami, P.R.; Rizvi, H.S.; Khan, W.A.; Basu, K.S. (1984). Studies on immobilized fungal spores for microbial transformation of steroids: 11 Hydroxylation of progesterone with immobilized spores of A. ochraceus $\mathrm{G} 8$ on polyacrylamide Gel and other matrices. Biotech. Bioeng., 26, 1403- 1408.

8. Capeck, A.; Tadra, M.; Tuma, J. (1964). Microbiological transformation of steroids XXIV. Separation androstane 17-hydroxyl epimers. Ebid, (9), 380.

9. Chitra, N.; Baradarajan, A. (1992). Direct conversion of starch hydrolysate to ethanol using a coimmobilizate of amyloglucosidase and Saccharomyces cervisiae in batch stirred tank reactor. Bioprocess. Biosyst. Eng., 7, 265-267. 
10. Cho, H.Y.; Yousef, A.E.; Yang, S.Y. (1996). Continuous production of pediocin by immobilized Pediococcus acidilactici PO2 packedbed bioreactor Appl. Microbiol. Biotechnol., 45, 589-594.

11. Datta, T.K.; Samanata, T.B. (1997). Novel catalytic activity of immobilized spores under reduced water activity. Bioorg. Med. Chem. Lett., 7, 283-288.

12. Dutta, K.T.; Samanta, B. (1999). Biconversion of progesterone by the activated immobilized Conidia of Aspergillus ochraceus TS Curr. Microbiol., 39, 309-312.

13. Errede, L.A.; Stosz, D.; Sirvin, M.I. (1986). Swelling of particulate polymers enmeshed in polytetrafluoroethylen. J. Appl. Ploymer Sci., 31, 2721-2737.

14. Fokina, V.V.; Arinbasarova, A.Y.U.; Zubov, L.A.; Lozinsky, V.L.; Koshcheenko, A.K. (1993). Dehydogenation of steroid substrates by the cells of Arthrobacter globiformis 193 incorporated in poly (vinyl alcohol) cryogels. Appl Biochem Microbiol., 31, 184-189.

15. Gemeiner P.; Bexova-Benkova, V.; Svec F.; Norrlow, O. (1994). Natural and synthetic carriers suitable for immobilization of viable cells, active organelles and molecules. In: Veliky I.A. \& McLean RJC. (eds) Immobilized biosystems. Theory and practical application, Chapman and Hall, London, Glasgow, New York, Tokyo, pp.1-128, 1994.

16. Goetschel, R.; Bar, R. (1992). Formation of mixed crystals in microbial conversion of sterols and steroids. Enzyme Microb. Technol., 14, 462-496.

17. Gough S.; McHale, A.P. (1988). Continuous ethanol production from molasses at $45^{\circ} \mathrm{C}$ using alginate-immobilized Kluveromyces marxiamus IMB3 in a continuous-flow bioreactor. Process. Eng., $19,33-36$

18. Hamdy, A.A. (1999). Transformation of progesterone to $11 \alpha-$ hydroxyprogesterone using Mucor racemosus NRRL.3639. Egypt J. Microbiol., 34, 167-179.

19. Isaias, O.; Savas, G.; Hatzikiriakos, S. (2004). Polytetrafluoroethylene (PTFE) paste performing: Viscosity and surface tension effects, Powder Technol., 146(1-2), 73-83.
20. Kosheyenko, K.A.; Turkino, M.V.; Shryabin, G.K. (1983). Immobilization of living microbial cells and their application for steroid transformation. Enzyme Microb. Technol., 5, 14-21.

21. Llanes, N.; Fernandes, P.; Leon, R.; Cabral, S.M.J.; Pinheiro, M.H. (2001). Conversion of â-sitosterol by Mycobacterium sp NRRL. B3805 cells immobilized on Celite supports. J. Mol. Cat., B: Enzyme, 11, 523-530.

22. Manosroi, J.; Manosroi, A.; Saraphanchatiwittaya, A.; Abe, M. (1999). Comparison of prednisolone production from cortexolone by free and immobilized isolated and standard collection strains using mixed culture techniques. J. Chem. Tech. Biotech., 74, 364-370.

23. Matthew, C.; Peterson, M.D. (1995). Progestogens, Progesterone antagonists, progesterone, and androgens: synthesis, classification and uses. Clin. Obstet. Gynecol., 38, 823-820.

24. Mazur, S. (1995). Paste extrusion of polytetrafluoroethelne fine powder, In : Mnarbis, N. Rosenzweig, (eds), Polymer Powder Technol. John Weily, New York. pp.441-481.

25. Okamoto, N.; Mayiyama, Y. (1978). Production method of PTFE porous materials, Japan patent S5342794.

26. Park, T.G.; Hoffman, A.S. (1990). Immobilization of Arthrobacter simplex in a thermally reversible hydrogel: effect of temperature cycling on steroid conversion. Biotechnol. Bioeng., 35, 152-159.

27. Rae, J.P.; Dattelbaum, M.D. (2004). The properties of (PTFE) in compression. Polymer, 45, 7615-7625.

28. Roisin, C.; Bienaime, C.; Nava Saucedo, J.E.; Baarbotin, J.N. (1996) Influence of microenvironment on immobilized Gibberella fujikuroi, Prog. Biotechnol., 11, 189-195.

29. Smith, L.L. (1984). Steoids In: Biotechnology, (eds) Rehm J.H. and Reed, G. Vol 6a. Verlag Chemie, Weinhemie, Germany.

30. Steinert, H.J.; Vrolop, D.K.; Klein, J. (1997). In: Laane, J.; Tramper, M.; Lilly, D. (EDS) Biocatalysis in organic media, Amsterdam. pp.51.

31. Zohri, A.A. (2000). Progesterone transformation as a biochemical aid in classification of the genus Emericella. Folia Microbiol., 45(5), 391-6. 